\title{
The Relationship among Speech Perception, Vocabulary Size and Articulation Accuracy in Children with Speech Sound Disorders
}

\author{
Seunghee Ha \\ Division of Speech Pathology and Audiology, Audiology and Speech Pathology Research Institute, Hallym University, Chuncheon, Korea
}

Correspondence: Seunghee $\mathrm{Ha}, \mathrm{PhD}$ Division of Speech Pathology and Audiology, Audiology and Speech Pathology Research Institute, Hallym University, 1 Hallimdaehak-gil, Chuncheon 24252, Korea

Tel: +82-33-248-2215

Fax: +82-33-256-3420

E-mail: shha@hallym.ac.kr

Received: January 5, 2016

Revised: February 18, 2016

Accepted: February 27, 2016

\begin{abstract}
Objectives: The purpose of this study is to investigate the ability to perceive final consonants of children with speech sound disorders (SSD) in comparison with typically developing children age 4 to 6 years old. This study also examines the relationship among speech perception, vocabulary size, and articulation accuracy. Methods: Thirty-three children with SSD and 35 typically developing (TD) children were asked to identify consonant-vowelconsonant one syllable words in whole words and gated conditions (-40 ms and $-60 \mathrm{~ms})$. The d-prime values were used to determine the children's ability to attend to fine phonetic details. Children with SSD were divided into two groups by comorbidity of language disorders and had their speech perception performances compared with TD children. A stepwise multiple regression was performed to investigate the relationship among speech perception, vocabulary size, and articulation accuracy. Results: Group differences appeared in both whole word and gated conditions. Children with SSD and language disorders showed no differences when compared with children showing articulation problems only in the whole word and -40 ms gated conditions. Both SSD groups showed lower speech perception than TD children. In the -60 ms gated condition, only children with SSD showed significantly lower speech perception performances than TD children. Receptive vocabulary size and articulatory accuracy were significant predictors of speech perception. Conclusion: The results suggest that children with SSD show deficits in speech perception and that the ability to attend to fine phonetic details is related to vocabulary size and articulation skills.
\end{abstract}

Keywords: Speech sound disorders, Speech perception, Vocabulary size, Articulatory accuracy
말지각은 말소리의 음향 신호에 포함되어 있는 세부적인 음성 정 보에 집중하여 말소리의 자질과 유형을 반영하는 정보를 처리하는 능력을 의미한다(Locke, 1980a, 1980b; Lof \& Synan, 1997). 아동의 말지각 발달 특성을 살펴본 연구에서는 일반적으로 아동의 연령이 낮을수록 낱말을 정확하게 구별하여 지각하기 위해서 더 많은 음향 정보가 필요하다고 하였다(Elliott, Hammer, \& Evan, 1987; Walley, 1988). 또한 음향 신호가 왜곡되거나 일부 삭제된 조건을 이용한 말 지각 연구에서도 성인과 비교해 아동은 음향 신호에 집중하여 정 확하게 소리를 지각하는 데 어려움을 보이고 이러한 수행상의 어려 움은 아동의 연령이 낮을수록 더 증가하였다(Byeon \& Ha, 2015;
Edwards, Fox, \& Rogers, 2002; Munson, 2001; Nittrouer, 1992). 이 러한 선행연구는 아동의 연령이 낮을수록 말소리를 정확하고 안정 적으로 구별하여 지각하기 위해서는 특정 말소리의 핵심적인 음향 학적인 단서 외에 여분의 음향학적 단서(redundancy of acoustic cue)를 필요로 함을 제안하고 있다. 특정 말소리를 지각하기 위해 필요한 최소한의 핵심적인 음향 정보를 확인하는 방법으로 게이팅 (gating) 과제가 있다. 이 과제는 단어의 시작 또는 끝부분의 음향 신호를 일정한 길이로 점진적으로 삭제하여 단어를 정확하게 지각 하지 못하는 지점을 측정하거나, 반대로 삭제된 음향 신호의 일부 분을 점진적으로 증가하여 제시하면서 단어를 정확하게 지각하는 
지점을 측정함으로써 특정 말소리를 지각하기 위해 필요한 최소한 의 핵심적인 음향 신호의 양과 특징을 결정하는 방법이다. 게이팅 과제를 이용한 국내 연구로 Byeon과 $\mathrm{Ha}$ (2015)는 만 4-6세 일반아 동과 성인을 대상으로 종성 파열음의 지각에 대한 발달패턴을 살 펴보았다. 연구결과 종성의 음향 신호가 일부 삭제된 상태에서 4,5 세 아동은 성인보다 유의하게 낮은 말지각력을 보였으나 6세 아동 은 성인과 유사하게 양호한 지각력을 보였다. 이는 아동이 말소리 를 정확하게 지각하기 위해서는 성인보다 더 많은 음향 정보를 필 요로 한다는 것을 제안한다. 또한 말지각 능력은 연령이 증가함에 따라 지속적으로 향상되어 일정 연령이 되면 성인과 같은 수준에 도달함을 제안하고 있다.

아동이 말-언어습득과정에서 어휘를 습득하고 정확한 말소리로 표현하기 위해서는 말소리의 음향 정보를 토대로 말소리의 차이를 감지하고 구분하는 말지각 능력이 필수적이다. 특히 말지각은 말소 리 산출상의 문제를 일으키거나 유지시키는 원인으로서 오랜 기간 동안 많은 연구자에 의해 논의되어 왔다(Hoffman, Daniloff, Bengoa, \& Stuckers, 1985; Hoffman, Stager, \& Daniloff, 1983; Locke, 1980a, 1980b; Lof \& Synan, 1997; Ohde \& Sharf, 1988; Wilcox \& Stephens, 1982). 검사어, 검사 조건 등을 포함한 연구방법이 선행연 구마다 다양하고 연구에 참여한 말소리장애 아동이 심각도, 원인, 오류 유형 등에서 다양한 특성을 보여 연구마다 결과가 상이하지 만, 일반아동에 비해 말소리장애 아동이 말소리를 구별하기 어렵 다는 결과가 좀 더 일반적이다(Cohen \& Diehl, 1963; Edwards et al., 2002; Prins, 1963). 말소리장애 아동을 대상으로 게이팅 과제를 이용한 연구 중 Edwards 등(2002)에서는 말소리장애 아동이 일반 아동에 비해 음향 신호가 모두 제공된 조건과 일부 삭제된 게이팅 조건 모두에서 종성 파열음에 대한 낮은 말지각력을 보였다. Edwards 등(2002)과 비슷한 실험 절차를 통해 말소리장애 아동과 일 반아동의 한국어 종성 파열음에 대한 지각력을 살펴본 Won과 $\mathrm{Ha}$ (2015) 연구에서는 자극어에 따라 결과가 다소 상이했지만 말소리 장애 아동이 전반적으로 일반아동에 비해 낮은 말지각력을 보였 다. 자극어 '목-못'에서는 일반아동도 정확하게 구별하는 데 어려 움을 보여 집단 간 차이가 통계적으로 유의미하지 않았지만 자극 어 ‘밭-밥’에서는 말소리장애 아동이 일반아동에 비해 유의미하게 낮은 말지각력을 보였다. 흥미로운 것은 일반아동은 종성의 음향 신호를 모두 제공한 조건과 $60 \mathrm{~ms}$ 삭제한 조건, $40 \mathrm{~ms}$ 와 $60 \mathrm{~ms}$ 삭 제한 조건 간 유의미한 차이를 보인 반면에 말소리장애 아동은 조 건 간 종성 지각력에 유의한 차이가 없었다. 일반아동은 종성파열 음을 완전하게 제공한 조건과 종성의 끝부분을 $40 \mathrm{~ms}$ 만큼 삭제한 조건에서는 종성을 토대로 낱말을 구별하는 데 어려움이 없었다.
하지만 말소리장애 아동은 음향 신호가 완전하게 포함된 조건에서 도 큰 어려움을 보여 음향 신호가 완전히 포함된 조건과 삭제된 조 건 간의 차이를 보이지 않았다. 이러한 연구 결과는 말소리장애 아 동이 보이는 말소리 지각상의 결함이 말소리 산출상의 문제를 일 으키고 유지시키는 원인이 될 수 있음을 제안하고 있다.

말지각은 정확한 말소리 산출뿐만 아니라 어휘를 습득하고 학습 하는 데 중요한 기본 전제조건이다. 아동은 성장하면서 음향 정보 를 토대로 음운 체계에 대한 추상적인 지식과 음운표상을 발달시 키는 동시에 특정 낱말에 대한 의미 및 어휘표상을 발달시켜 나간 다. 아동의 추상적인 심상 어휘집(lexicon)에는 음운표상, 의미 및 어휘표상과 함께 특정 말소리의 조음 움직임과 관련된 추상적인 운동 지식을 나타내는 운동 프로그램이 포함되어 있다(Stackhouse \& Wells, 1997). 따라서 심상 어휘집에 저장되어 있는 특정 어휘를 인출하여 산출하기 위해서는 말소리의 음성적 변별, 음운 인식, 음운표상, 의미 및 어휘표상, 운동 프로그램으로 이어지는 말 처리 과정이 원활하게 이루어져야 한다. 아동이 말-언어를 습득하 는 과정에서 말소리의 음성적 변별 및 지각상의 어려움을 보일 경 우 말 처리 과정의 상위 단계인 음운인식, 음운표상, 의미 및 어휘표 상, 운동 프로그램의 발달이 원활하게 이루어지기 어렵고, 이것은 표면적으로 말산출 오류와 어휘 습득상의 문제로 나타날 것이다. 말지각의 일부 선행연구에서는 아동의 어휘크기(vocabulary size) 가 말지각 능력과 유의미한 상관이 있었다(Edwards et al., 2002; Munson, 2001; Werker, Fennell, Corcoran, \& Stager, 2002). 예를 들어 생후 14-20개월 아동을 대상으로 말지각과 어휘크기의 관계 를 살펴본 Werker 등(2002) 연구는 14 개월 아동의 경우 수용 및 표 현 어휘크기가 아동이 새롭게 접하는 최소대립쌍 낱말을 지각하 는 능력과 유의미한 상관이 있음을 발견하였다. 또한 연구자는 많 은 단어를 습득한 어린 연령의 아동일수록 단어 내 세밀한 음향 정 보에 더 잘 집중하고, 모든 월령대에서 세밀한 음향 정보에 잘 집중 할 수 있는 아동일수록 단어를 더 잘 학습한다고 제안하였다.

말지각이 말소리 산출뿐만 아니라 어휘 습득을 포함하여 언어 발달과 밀접한 관계를 보인다는 점은 언어문제를 동반한 말소리장 애 아동은 단순히 조음만의 문제를 가진 말소리장애 아동과는 다 른 양상을 보이거나 더 큰 어려움을 보일 수 있음을 나타낸다. 게이 팅 과제를 이용하여 말소리장애 아동의 말지각 능력을 살펴본 Edwards 등(2002)의 연구는 일반아동과 비교해서 통계적으로 유의 하게 낮은 표현어휘 점수를 받은 말소리장애 아동을 대상으로 진 행되었다. 반면에 Won과 $\mathrm{Ha}$ (2015) 연구에서는 수용-표현 어휘력 검사(REVT; Kim, Hong, Kim, Jang, \& Lee, 2009)를 실시하여 -1 $\mathrm{SD}$ 이상으로 수용 및 표현 어휘발달이 정상인 것으로 확인된 말소 
리장애 아동만이 집단에 포함되었다. 두 연구결과가 비슷하게 말소 리장애 아동의 말지각상의 어려움을 제시하였지만 말소리장애 아 동의 특성에 따라 말지각 능력이 달라지는지 좀 더 자세하게 살펴 볼 필요가 있다. 말소리장애의 원인과 동반 문제에 따라 말소리장 애 아동이 다양한 특성을 보이고, 그에 따라 차별적인 중재 접근법 을 제공해야 할 필요성(Dodd, 2005)을 고려한다면 말소리장애 아 동을 다양한 기준으로 분류하여 특성을 자세히 살펴보는 연구가 필요하다. 본 연구에서는 종성파열음의 지각에 초점을 맞추어 일 반아동과 비교하여 말소리장애 아동이 말지각상의 어려움을 보이 는지 살펴보고자 한다. 구체적으로 조음문제만 보이는 말소리장애 아동과 언어장애를 동반한 말소리장애 아동의 말지각 능력을 비교 하고자 한다. 또한 말지각 능력과 어휘력, 자음정확도와의 관계를 살펴봄으로써 말-언어습득 과정에서 말지각 능력의 역할에 대해서 알아보고자 한다.

\section{연구 방법}

\section{연구대상}

만 4-6세 말소리장애 아동 33명과 생활연령을 일치시킨 일반아 동 35 명을 대상으로 하였다. 말소리장애 아동은 (1) 아동용발음평 가(APAC; Kim, Pae, \& Park, 2007)를 실시하였을 때 백분위수가 $16 \%$ ile (-1 SD) 이하에 속하며 (2) 순음청력 검사 시 $500,1,000$, $2,000,4,000 \mathrm{~Hz}$ 에서 청력역치가 $20 \mathrm{dBHL}$ 이하로 정상 청력을 보였 으며 (3) 말 산출 및 청각기관의 구조나 감각상의 문제와 신드롬과 같은 유전적 문제를 보이지 않았다. 세부적으로 말소리장애 아동 은 수용·표현 어휘력 검사(REVT; Kim et al., 2009)를 실시하여 표 준편차 - $\mathrm{SD}$ 이상인 경우에는 단순말소리장애 집단(20명)으로 -1 $\mathrm{SD}$ 이하인 경우에는 언어문제를 동반하는 말소리장애 집단(13명) 으로 분류하였다. 말소리장애 아동은 모두 APAC 검사에서 어말 종성이나 어중종성에서 1 회 이상의 오류를 보였다. 일반아동은 (1) $\mathrm{APAC}$ (Kim et al., 2007)에서의 백분위수가 $16 \%$ ile 이상에 속하며, (2) 순음청력 검사 시 $500,1,000,2,000,4,000 \mathrm{~Hz}$ 에서 청력역치가 $20 \mathrm{dBHL}$ 이하로 정상 청력이고, (3) REVT (Kim et al., 2009)에서 는 표준편차 -1 SD 이상이고, (4) 그 외 구강구조 및 발달상에 별다 른 어려움이 없는 것으로 보고된 아동으로 선정하였다.

본 실험에 포함된 말소리장애 아동과 일반아동에 대한 기본정 보와 언어 및 조음평가결과는 Table 1 과 같다. 단순말소리장애와 언어문제를 동반한 말소리장애 아동과 일반아동의 평균 연령은 각 각 61.18 (SD 7.22), 62.54 (SD 8.99), 63.23 (SD 9.34)개월로 연령에 대한 일원분산분석을 실시한 결과 통계적으로 집단 간 유의한 차
Table 1. Subjects' information

\begin{tabular}{lcccc}
\hline & \multicolumn{2}{c}{$\operatorname{SSD}$} & \multirow{2}{*}{$\operatorname{TD}(\mathrm{N}=35)$} & $F$ \\
\cline { 2 - 3 } & $\mathrm{AD}(\mathrm{N}=20)$ & $\mathrm{SLD}(\mathrm{N}=13)$ & & \\
\hline Age (yr;mo) & $5 ; 0$ & $5 ; 2$ & $5 ; 3$ & .978 \\
Gender (boy:girl) & $14: 6$ & $9: 4$ & $21: 14$ & \\
REVT-R score & $55.35(10.57)$ & $40.92(15.62)$ & $62.51(14.39)$ & $11.94^{*}$ \\
REVT-E score & $61.35(8.34)$ & $47.77(15.76)$ & $68.51(11.52)$ & $15.16^{*}$ \\
APAC PCC $(\%)$ & $76.58(21.92)$ & $84.12(7.00)$ & $97.43(2.89)$ & $19.10^{*}$ \\
\hline
\end{tabular}

Values are presented as number or mean (SD).

$A D=$ articulation disorders only; $S L D=$ speech and language disorders; $S S D=$ speech sound disorders; TD =typically developing children; REVT = Receptive \& Expressive Vocabulary Test (Kim, Hong, Kim, Jang, \& Lee, 2009); APAC=Assessment of Phonology \& Articulation for Children (Kim, Pae, \& Park, 2007); PCC= percentage of consonants correct.

${ }^{*} p<.0001$.

이를 보이지 않았다. 세 집단으로부터 수집된 REVT 수용 및 표현 어휘 원점수와 APAC상의 자음정확도는 Table 1 과 같다. 세 집단의 특징을 살펴보기 위해 REVT 수용 및 표현어휘 원점수와 APAC상 의 자음정확도를 각각 종속변인으로 일원분산분석을 실시한 결과 세 종속변인에서 집단 간 차이가 유의미한 것으로 나타났다. 이에 대한 Scheffe 사후분석 결과 REVT 수용과 표현 어휘 원점수는 모 두 언어문제를 동반한 말소리장애 아동이 단순말소리장애와 일반 아동과 유의미한 차이를 보였으나 단순말소리장애와 일반아동은 서로 유의한 차이를 보이지 않았다. 자음정확도에 대한 사후분석 결과는 일반아동이 두 말소리장애 집단과 유의한 차이를 보였으나 두 말소리장애 집단 간에는 유의한 차이가 없었다. 말소리장애 아 동 중 언어치료력이 없는 3 명을 제외하고는 모든 아동은 실험 전 또 는 당시에 언어치료를 받고 있었다.

\section{말지각 과제}

본 연구에 사용된 말지각 과제의 검사어 및 제시 방법은 Won과 $\mathrm{Ha}$ (2015)에 기술된 예비실험을 통해 최종 선정되었다. 말지각 과제 의 초점이 된 종성은 우리말에서 종성으로 올 수 있는 파열음, 비 음, 유음 간의 전체적인 음향학적 길이와 특성이 다름을 고려하여 파열음 종성만을 선정하였다. 예비실험을 통해 종성의 조음방법을 파열음으로 일치시키고 조음위치만 다르게 한 '목-못[몯]', '밥-밭 [받]' 낱말 2쌍을 최종 선정하였다. 자극어는 20대 정상 성인 여성이 Computerized Speech Lab (CSL, model 4150)을 사용하여 녹음하 였다. 그 후 여러 가지 길이 $(20,40,50,60 \mathrm{~ms})$ 로 게이팅 조건을 만들 어 성인과 아동을 대상으로 예비실험을 실시하였다. 그 결과 $40 \mathrm{~ms}$ 과 $60 \mathrm{~ms}$ 만큼 음향 정보를 삭제한 2 개의 게이팅 조건이 말지각의 발달 패턴이나 결함 여부를 효율적으로 반영할 것으로 판단되어 이 두 조건을 최종 게이팅 실험 과제로 선택하였다. 
말지각 과제는 Superlab version 4.5 (model RB-834) 프로그램을 이용하여 자극어가 헤드폰을 통해 청각적으로 제시된 후 바로 해 당하는 한 쌍의 그림이 노트북 화면에 제시되도록 하였다. 실험 동 안 제공되는 그림 자극은 재미있는 언어치료(Kim, 2006)와 언어발 달 촉진을 위한 우리말카드(Kim, Ki, Jin, \& Pae, 2013), 상황전개카 드 '어디' (핑키밍키)에서 선택하였다. 그림자극을 가로 $9 \mathrm{~cm} \times$ 세 로 $8 \mathrm{~cm}$ 크기로 편집 후 $5 \mathrm{~cm}$ 간격을 두고 노트북 한 화면에 두 가 지 그림이 나란히 제시되도록 하였다. 예비실험에서는 좌측버튼은 노트북 화면의 좌측그림과 우측버튼은 우측그림과 연결된 Super$\mathrm{lab}$ 의 반응패드(response pad)를 이용하여 피험자가 직접 반응하 도록 하였다. 하지만 일부 어린 연령의 아동들이 반응패드의 버튼 을 한쪽만 누르거나, 번갈아 누르는 등 반응패드와 그림의 방향을 연결 짓는 데 어려움을 보였다. 따라서 본 실험에서는 아동에게 자 극어를 듣고 노트북 모니터의 해당 그림을 지적하도록 하였고, 검 사자가 반응패드를 이용하여 아동의 반응을 기록하였다.

말지각 과제를 실시하기에 앞서 먼저 자극어 그림에 대한 아동의 이해와 표현 정도를 확인하였다. 아동이 그림에 해당하는 어휘를 모를 경우 아동에게 이름과 뜻을 충분히 알려준 후 아동이 자발적 으로 어휘의 이름을 말할 수 있는지를 확인하였다. 말지각 과제에 서는 4 개의 자극어와 3 개의 조건(전체, $-40 \mathrm{~ms},-60 \mathrm{~ms}$ )을 총 4 회씩 반복하여 총 48 개의 자극을 무작위로 제공하였다. 아동에게 한 번 에 많은 자극을 들려 줄 경우피로로 인해 아동이 끝까지 과제를 적 절하게 수행하지 못할 가능성이 있으므로 말지각 과제를 두 세트 로 나누고 중간에 휴식시간을 제공하였다. 따라서 말지각 과제는 두 세트로 동일하게 나뉘어 4 개의 자극어 $\times 3$ 개의 조건 $\times 2$ 회 반복 으로 총 24 개의 자극으로 각각 구성되었다.

\section{실험 절차 및 자료 수집}

본 연구의 실험 절차와 자료 수집은 Won과 $\mathrm{Ha}$ (2015)에 기술된 바와 동일하게 이루어졌다. 아동의 어린이집, 가정 혹은 언어치료실 등 조용한 상황에서 자료 수집이 이루어졌으며, 사전 검사인 말-언 어검사 및 순음청력 검사와 본 검사인 말지각 검사를 2 회에 걸쳐 수집하였다. 먼저 REVT 수용·표현어휘 검사와 APAC 검사를 실시 한 후 청력검사와 말지각 검사를 진행하였다. 청력검사는 portable audiometer 기기를 이용하여 독립된 공간에서 진행하였다. 순음청 력 검사는 $500,1,000,2,000,4,000 \mathrm{~Hz}$ 주파수 대역에서 실시하였으 며, $20 \mathrm{~dB}$ 이하에서 소리에 대한 반응을 보이는 경우, 자극을 더 이 상 제공하지 않고 정상청력으로 판정하였다.

말지각 검사는 '곰-공', '삼-사' 짝으로 이루어진 8개의 연습문항 과 활동을 통해 아동에게 검사의 과정을 충분히 이해하고 숙지시
켰다. 연습문항은 말지각 검사방법에 아동이 익숙해지기 위한 단 계이기 때문에 종성의 음향 정보가 모두 제공된 조건만을 제시하 였다. 먼저 연습 문항과 본 문항의 어휘를 확인하는 시간을 가진 후 아동이 검사어와 검사 과정을 잘 이해하는 모습을 보일 경우 말지 각 검사를 진행하였다. 말지각 검사 도중에 아동이 주의 집중하지 못하고 검사를 끝까지 수행하지 못하거나 청각적 자극을 듣고 과제 를 판단하는 것이 아니라 단순히 한 가지 그림만으로 지속적으로 반응하는 모습이 뚜렷할 경우 최종 연구 자료에서 제외시켰다.

\section{자료 분석 및 통계처리}

아동의 수행력을 정반응 수와 오반응 수를 토대로 산출하는 dprime 값을 이용하여 측정하였다. d-prime 값은 반응에 대한 민감 성을 보다 타당하게 반영하는 측정치이다(Macmillan \& Creel$\operatorname{man}, 2005)$. '예-아니요' 과제나 두 개의 그림 중 하나를 고르는 과 제에서는 피험자가 두 가지 중 하나로 반응하여 우연한 기회에 정 반응할 수 있는 확률이 $50 \%$ 로 높다. 따라서 단순히 정반응률을 측 정치로 사용하는 경우에는 개인의 수행력을 신뢰롭게 반영할 수 없다. 이러한 점을 보완하기 위해 d-prime 값은 정반응(hit alarm) 수와 오반응(false alarm) 수를 모두 고려하여 산출된다. d-prime 값을 구하는 방법은 아동의 정반응 확률 $(\mathrm{P}(\mathrm{h}))$ 과 오반응 확률 $(\mathrm{P}(\mathrm{fa}))$ 을 구한 다음, 정반응 확률의 $Z$ 값에서 오반응 확률의 $Z$ 값을 빼서 계산한다. 만약 확률이 0 또는 1 인 경우 $Z$ 값은 무한대가 되기 때문에, 확률 값이 0 인 경우는 $1 /(2 \times$ 자극어 개수)을 대입하고, 확 률 값이 1 인 경우에는 1-(1/2×자극어 개수)을 대입하여, $Z$ 점수 값 을 산출하였다(Macmillan \& Kaplan, 1985; Stanislaw \& Todorov, 1999). d-prime 값이 0 인 경우에는 정반응과 오반응 확률이 같음을 의미하고, 0 이상인 경우에는 정반응이 오반응 확률보다 큼을 의미 한다. 따라서 d-prime 값이 클수록 자극어의 음향 정보를 토대로 아동이 정확하게 반응하였음을 의미한다.

자료의 통계분석은 PASW 20.0을 사용하였으며, 4 개의 자극어 를 이용하여 3 개의 조건(전체, $-40 \mathrm{~ms},-60 \mathrm{~ms}$ )에 따라 말소리장애 아동 두 집단과 일반아동 간 말지각력의 차이를 확인하기 위해 일 원분산분석을 실시하였다. 세 집단(단순말소리장애, 언어문제를 동반한 말소리장애, 일반아동) 비교 시 유의미한 집단 간차이를 보 일 경우 Scheffe 사후검정을 실시하였다. 또한 말지각 능력과 연령, 수용 및 표현 어휘크기와 자음정확도의 관계를 살펴보기 위해서 단계식 회귀분석(stepwise multiple regression)을 실시하였다. dprime 값을 종속변수로 하고 연령, REVT 표현어휘 원점수, REVT 수용언어 원점수, $\mathrm{APAC}$ 원점수를 독립변수로 하여 회귀분석을 실 시하였다. 
Table 2. d-prime values for all conditions by group

\begin{tabular}{lcccc}
\hline & \multicolumn{2}{c}{ SSD } & SSD & TD \\
\cline { 2 - 3 } & AD & SLD & & \\
\hline Whole word & $1.27(1.20)$ & $.66(.84)$ & $1.03(1.10)$ & $2.12(.78)$ \\
$-40 \mathrm{~ms}$ & $1.06(1.31)$ & $.60(.82)$ & $.88(1.15)$ & $1.81(.71)$ \\
$-60 \mathrm{~ms}$ & $.92(.82)$ & $.34(.66)$ & $.69(.81)$ & $1.23(.89)$ \\
Mean & $1.08(.97)$ & $.53(.55)$ & $.87(.86)$ & $1.72(.60)$ \\
\hline
\end{tabular}

Values are presented as number or mean (SD).

$A D=$ articulation disorders only; $S L D=$ speech and language disorders; $S S D=$ speech sound disorders (AD + SLD); TD = typically developing children.

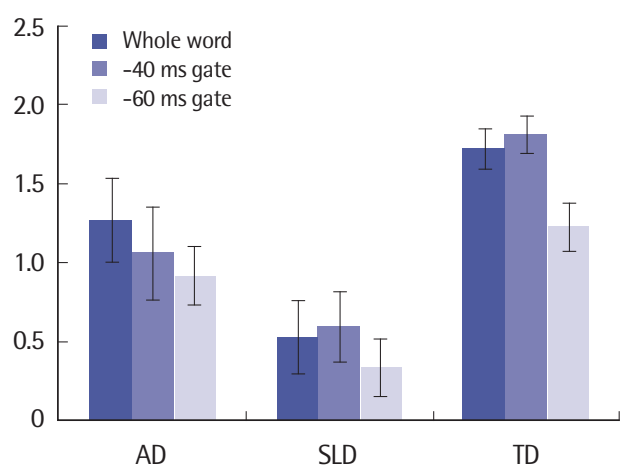

Figure 1. Mean d-primes with standard errors by group and gating condition. $A D=$ articulation disorders only; $S L D=$ speech and language disorders: $\mathrm{TD}=$ typically developing children.

\section{연구 결과}

\section{집단 간 말지각 수행력의 차이}

3 가지 음향 조건(전체, $-40 \mathrm{~ms},-60 \mathrm{~ms}$ )에서 측정한 집단별 dprime 값의 평균과 표준편차는 Table 2, Figure 1과 같다. 먼저 언어 문제 동반 여부와 상관없이 모든 말소리장애 아동과 일반아동의 말지각 수행력을 살펴보면 3가지 음향 조건 모두에서 말소리장애 아동이 일반아동보다 낮은 d-prime 값을 보였다. 말소리장애 아동 내에서 살펴보면 언어문제를 동반한 말소리장애 아동이 단순말소 리장애 아동보다 모든 음향 조건에서 낮은 d-prime 값을 보였다. 조 건별로 아동의 수행력을 살펴보면 세 집단 모두 자극어 전체를 들 려준 조건에서 d-prime 값이 가장 높았고, $-40 \mathrm{~ms},-60 \mathrm{~ms}$ 게이팅 조건으로 갈수록 d-prime 값이 낮아졌다.

일원분산분석을 통해 세 집단 간 차이를 검정한 결과 전체 $\left(F_{(2,68)}\right.$ $\left.=13.302, p<.001, \eta_{\mathrm{p}}{ }^{2}=.290\right),-40 \mathrm{~ms}\left(F_{(2,68)}=9.213, p<.001, \eta_{\mathrm{p}}{ }^{2}=\right.$ $.221),-60 \mathrm{~ms}\left(F_{(2,68)}=5.5267, p<.001, \eta_{\mathrm{p}}{ }^{2}=.145\right)$ 조건 모두에서 집 단 간 d-prime 값이 유의미한 차이를 보였다. Scheffe 사후분석결 과, 전체와 $-40 \mathrm{~ms}$ 게이팅 조건에서는 단순말소리장애와 언어문제 를 동반한 말소리장애 집단 간에는 유의미한 차이를 보이지 않았으
Table 3. Results of stepwise regression analysis

\begin{tabular}{lccccc}
\hline & $\mathrm{B}$ & $\beta$ & $\mathrm{R}^{2}$ & $t$ & $p$ \\
\hline $\begin{array}{l}\text { Speech perception } \\
\text { (constant) }\end{array}$ & .307 & & & & \\
$\quad \begin{array}{l}\text { REVT receptive vocabulary } \\
\quad \text { raw score }\end{array}$ & .021 & .389 & .247 & 3.321 & .001 \\
$\quad$ APAC raw score & -.026 & -.236 & .291 & -2.015 & .048 \\
\hline
\end{tabular}

REVT $=$ Receptive \& Expressive Vocabulary Test (Kim, Hong, Kim, Jang, \& Lee, 2009); $A P A C=$ Assessment of Phonology \& Articulation for Children (Kim, Pae, \& Park, 2007).

나 두 집단은 모두 일반아동과는 d-prime 값의 유의미한차이를 보 였다. $-60 \mathrm{~ms}$ 게이팅 조건에서는 언어문제를 동반한 말소리장애 집 단과 일반아동집단 간의 유의미한 차이만 보였다. 즉 단순말소리장 애 집단은 언어문제를 동반한 말소리장애뿐만 아니라 일반아동 집 단과도 유의미한 차이를 보이지 않았다.

\section{말지각 능력과 연령, 수용 및 표현어휘력 및 자음정확도와의 관계}

아동의 모든 자극어와 조건에서의 d-prime 값을 종속변수로 하 고 연령, REVT 표현어휘 원점수, REVT 수용어휘 원점수, APAC 원점수를 독립변수로 하여 단계식 회귀분석을 실시한 결과는 Table 3 과 같다. 분석 결과, $\mathrm{R}^{2}=.291$ 으로 REVT 수용어휘 원점수와 $\mathrm{APAC}$ 원점수가 유의미한 예측치로 나타났다. 수용어휘 원점수가 d-prime 값의 변화 중 $24.7 \%$ 를 설명하고 APAC 원점수가 d-prime 값의 변화중 $4.4 \%$ 를 설명하였다.

\section{논의 및 결론}

본 연구는 종성파열음의 지각에 초점을 맞추어 낱말의 음향 신 호를 모두 들려준 조건과 종성의 일부를 삭제한 게이팅 조건에서 말소리장애 아동의 말지각 능력이 일반아동과 비교하여 어떠한지 살펴보고자 하였다. 언어문제 동반 유무에 따라 말소리장애 아동 이 보이는 말지각상의 어려움과 특징을 이해하기 위해 조음문제만 보이는 단순말소리장애 아동과 언어문제를 동반하는 말소리장애 아동을 나누어 말지각 능력을 비교하였다. 연구결과 전체, $-40 \mathrm{~ms}$, $-60 \mathrm{~ms}$ 조건 모두에서 집단 간 말지각 능력의 유의미한 차이를 보 였다. 검사어를 제시하는 조건에 따라 집단 간 차이를 살펴본 사후 분석결과는 집단 간 차이가 다소 다르게 나타났다. 음향 정보를 모 두 제공한 조건과 종성의 끝 구간을 $-40 \mathrm{~ms}$ 만큼 삭제한 조건에서 는 단순말소리장애와 언어문제를 동반한 말소리장애 집단 간에는 유의미한 차이를 보이지 않았고 두 집단은 모두 일반아동보다 유의 
미하게 낮은 말지각 수행력을 보였다. $-60 \mathrm{~ms}$ 게이팅 조건에서는 언 어문제를 동반한 말소리장애 집단과 일반아동 집단 간의 유의미한 차이만 보였다. 단순말소리장애 집단은 언어문제를 동반한 말소리 장애와 일반아동 집단과 비교해 중간 정도의 수행력을 보이면서 두 집단과 유의미한 차이를 보이지 않았다. 이러한 결과는 검사어 의 핵심적인 정보뿐만 아니라 여분의 정보가 포함된 안정적인 음향 신호를 지각하는 능력은 언어문제 동반 유무에 상관없이 말소리장 애 아동이 일반아동보다 낮다는 것을 제시한다. 검사어의 여분의 정보가 상대적으로 크게삭제된 불리한 조건에서는 일반아동도 단 순말소리장애 아동만큼 어려움을 보여 두 집단 간 차이를 보이지 않았다. 언어문제를 동반한 말소리장애 아동은 종성에 대한 정보 가 최소로 포함된 조건에서 같은 연령대의 일반아동보다 뚜렷하게 음성 정보를 토대로 단어를 구별하여 인지하는 능력이 떨어짐을 제 시하고 있다. 만 4-6세 일반아동과 성인을 대상으로 종성파열음의 지각에 대한 발달패턴을 살펴 본 Byeon과 $\mathrm{Ha}$ (2015)에서는 4, 5세 아동은 성인보다 종성의 일부 끝 구간이 삭제된 상태에서는 말을 정확하게 지각하는 데 어려움을 보였으나 6세 아동은 종성의 음향 신호가 일부 삭제된 상태에서도 성인과 유사하게 양호한 지각력을 보이는 것으로 나타났다. 이러한 연구결과는 말지각 능력은 아동 이 성장함에 따라 지속적으로 향상되고, 연령이 낮을수록 말소리 를 정확하게 지각하기 위해서는 더 많은 음성 정보를 필요로 함을 제시한다. 이러한 Byeon과 $\mathrm{Ha}$ (2015)의 연구결과를 토대로 본 연구 결과를 해석하면 언어문제를 동반한 말소리장애 아동은 말소리를 정확하게 지각하기 위해서는 연령이 낮은 일반아동처럼 보다 더 풍 부하고 안정적인 음향 신호를 필요로 한다고 할 수 있다.

아동의 말지각과 중요하게 관련 있는 요인을 살펴보기 위해서 모 든 자극어와 조건에서의 d-prime 값의 평균을 종속변수로 하고 연 령, REVT 표현어휘 원점수, REVT 수용언어 원점수, $\mathrm{APAC}$ 원점수 를 독립변수로 하여 단계식 회귀분석을 실시하였다. 분석 결과, $\mathrm{R}^{2}$ 이 .291으로 REVT 수용어휘 원점수와 APAC 원점수가 유의미한 예측치인 것으로 나타났다. 수용어휘점수가 d-prime 값의 변화 중 $24.7 \%$ 를 설명하고 $\mathrm{APAC}$ 원점수가 d-prime 값의 변화 중 $4.4 \%$ 를 설명하는 것으로 나타났다. 이러한 연구결과는 'cap/cat'과 'tap/ tack'을 토대로 단어 전체를 제시한 조건에서 3-8세 음운장애 아동 과 일반아동의 말지각을 살펴본 Edwards 등 (2002)의 연구와 거의 동일하다. 선행연구에서도 본 연구와 동일하게 수용어휘력이 말지 각을 가장 강하게 예측하였고 그 다음으로 자음정확도가 유의미 하게 말지각을 예측하였다. 반면에 두 연구 모두 아동의 연령은 말 지각을 유의하게 예측하지 못하였다. 따라서 본 연구와 선행연구 결과를 종합해 본다면 연령에 상관없이 수용어휘력과 자음정확도
가 높은 아동일수록 음성 정보를 집중하여 듣고 처리하여 정확하 게 단어를 구별하여 인지하는 능력이 높다고 할 수 있다. 특히 수용 어휘 점수가 가장 강한 말지각의 예측치라는 결과는 어휘 능력과 말지각의 관계를 제안한 선행연구(Edwards et al., 2002; Munson, 2001; Werker et al., 2002)를 지지하면서 세부적인 음성 정보에 집 중을 잘하는 아동이 어휘를 학습하고 습득하는 능력이 높음을 제 안하고 있다.

본 연구는 말소리장애 아동은 일반아동보다 음향 정보가 불완 전하게 제시된 조건뿐만 아니라 완전하고 풍부하게 포함된 조건에 서도 말소리를 정확하게 지각하고 단어를 구별하여 맞추는 능력이 떨어진다는 선행연구 결과(Edwards et al., 2002; Won \& Ha, 2015) 를 일관되게 지지하고 있다. 하지만 언어문제 동반 여부에 따라서 말소리장애 아동이 상대적으로 양호하거나 떨어지는 말지각 능력 을 보일 수 있는 가능성에 대해서는 부분적인 결과만을 제시하고 있다. 자음정확도보다 수용어휘력이 말지각 능력을 보다 더 강하 게 예측하는 것으로 나타난 회귀분석결과는 언어문제 특히 수용 어휘상의 문제를 동시에 보이는 말소리장애 아동이 단순말소리장 애보다 말지각상의 더 큰 어려움을 보일 수 있음을 제안한다. 하지 만 실제 세 집단의 수행력을 비교한 결과는 전체적으로 모든 조건 에서 단순말소리장애 집단이 언어문제를 동반한 말소리장애 집단 보다 높은 말지각 평균 점수를 보였지만 두 집단간 차이는 통계적 으로 유의하지는 않았다. 단순말소리장애와 언어문제를 동반한 말 소리장애 아동이 비슷한 말지각력을 보인 연구결과에 대한 이유로 아동이 보이는 오류 유형과 관련이 있을 수 있다. 두 말소리장애 집 단을 구성하는 아동들은 모두 APAC상에서 종성오류를 1 회 이상 으로 보인 것으로 확인되었다. 하지만 두 집단 모두 빈번하게 어말 종성을 생략하는 아동부터 어중 종성과 초성 위치의 자음연쇄 상 황에서 종성을 동화시킨 아동까지 종성오류의 유형과 심각도 면에 서 다양한 아동들로 구성되어 있다. 일부 선행연구는 말소리장애 아동이 보편적인 말지각상의 어려움을 보이기보다는 정확하게 산 출하지 못하는 음소에 국한하여 지각상의 어려움을 보인다고 제안 하였다(Hoffman et al., 1985; Locke, 1980a, 1980b; Rvachew \& Grawburg, 2006; Rvachew \& Jamieson, 1989). 이 점을 고려한다면 종성 오류의 심각도와 양상 면에서 두 집단의 차이가 나지 않고 다양한 아동들로 구성되어 종성의 지각에서도 집단 간 큰 차이를 보이지 않는 것일 수 있다. 이에 대해서 추후연구를 통해 종성에 대한 심화 검사를 실시하여 언어문제 동반 여부뿐만 아니라 말지각 검사에 사용된 어말종성 오류 여부에 따라 말소리장애 아동의 말지각력 이 어떠한지 살펴봐야 할 것이다. 이러한 연구는 말소리장애 아동 이 보편적인 말지각상의 결함을 보이는지 산출 오류를 보이는 음소 
에 국한되어 어려움을 보이는지 밝힐 수 있을 것이다.

말지각이란 말소리의 음향 신호를 “집중하여 듣고” 말소리의 자 질과 유형의 차이를 감지하고 구별하는 것을 지칭하는 것으로서 (Locke, 1980a, 1980b; Lof \& Synan, 1997), 본질적으로 선택적 주의 집중과 청각 및 음운기억과 같은 집행기능과 밀접한 관련이 있다. 말소리장애와 청각 처리와의 관계를 살펴본 Dodd (2005)가 논하 였듯이 심리음향처리상의 능력은 감각보다는 인지능력을 반영한 다고 할 수 있다. 더욱이 의미 있는 단어를 말지각 과제로 사용한 경 우는 음운기억 및 음운표상뿐만 아니라 어휘표상과도 관련이 있 다. 대다수의 말지각 연구가 그러하듯이 본 연구에서도 말지각 능 력을 살펴보는 과제는 아동의 선택적 주의집중, 청각 및 음운기억, 음운 및 어휘표상에 의존하고 아동의 말지각 점수는 집행기능 및 인지능력을 모두 포함하는 것이라 할 수 있다. 말지각을 집행기능 및 인지능력을 배제하고 살펴보기는 어려운 점이 있으나 말지각과 말소리 산출의 정확도, 어휘 습득 및 발달의 관계를 보다 더 명확하 게 밝히기 위해서는 추후연구에서 이에 대한 체계적인 고찰과 실험 상의 통제가 이루어질 필요가 있겠다.

본 연구는 음향 정보를 모두 제공하거나 말소리의 시간적 길이와 관련된 여분의 음향 정보를 일부 삭제하여 제공함으로써 일반아 동과 말소리장애 아동의 종성 지각력을 비교하여 살펴보았다. 말소 리장애 아동은 일반아동보다 음향 정보가 불완전하게 제시된 조건 뿐만 아니라 완전하고 풍부하게 제시된 조건에서도 말소리를 정확 하게 지각하는 능력이 떨어졌다. 자음정확도보다도 수용어휘력이 아동의 말지각력을 강하게 예측한다는 결과를 보여주면서 언어문 제를 동반한 말소리장애 아동이 말지각상의 결함을 보일 가능성 이 가장 높음을 제시하고 있다. 본 연구에서는 종성파열음 지각에 초점을 맞추었지만 제한된 수의 검사어를 사용하였고 종성오류의 심각도와 유형면에서 다양한 말소리장애 아동이 실험에 참여하였 다. 후속 연구에서는 여러가지 음향음성학적 조건과 특징이 반영 된 검사어를 이용하여 말소리장애 아동의 말지각을 좀 더 구체적 으로 살펴볼 필요가 있다. 또한 더 많은 수의 말소리장애 아동을 모 집하여 말소리 오류 유형과 심각도 등을 토대로 집단을 구분하여 말산출과 말지각과의 관계를 보다 심도있게 살펴볼 필요가 있겠다.

\section{REFERENCES}

Byeon, K., \& Ha, S. (2015). The final stop consonant perception in typically developing children aged 4 to 6 years and adults. Journal of the Korean Society of Speech Sciences, 7, 57-65.

Cohen, J. H., \& Diehl, C. F. (1963). Relation of speech-sound discrimination ability to articulation-type speech defects. Journal of Speech and Hearing Disorders, 28, 187-190.

Dodd, B. (2005). Differential diagnosis and treatment of children with speech disorder. London: Whurr.

Edwards, J., Fox, R. A., \& Rogers, C. L. (2002). Final consonant discrimination in children: effects of phonological disorder, vocabulary size, and articulatory accuracy. Journal of Speech, Language, and Hearing Research, 45, 231-242.

Elliott, L. L., Hammer, M. A., \& Evan, K. E. (1987). Perception of gated, highly familiar spoken monosyllabic nouns by children, teenagers, and older adults. Perception \& Psychophysics, 42, 150-157.

Hoffman, P. R., Daniloff, R. G., Bengoa, D., \& Schuckers, G. H. (1985). Misarticulating and normally articulating children's identification and discrimination of synthetic [r] and [w]. Journal of Speech and Hearing Disorders, 50, 46-53.

Hoffman, P. R., Stager, S., \& Daniloff, R. G. (1983). Perception and production of misarticulated /r/. Journal of Speech and Hearing Disorders, 48, 210215.

Kim, D. R. (2006). Workbook of speech therapy (Vol 2. Clinical speech therapy of articulation phonological disorders). Seoul: Paradise Welfare Foundation.

Kim, H. J., Kim, M. B., Jin, Y. S., \& Pae, S. (2013). Korean words card for for promoting language development. Seoul: Hakjisa.

Kim, M. J., Pae, S., \& Park, C. I. (2007). Assessment of phonology for children (APAC). Incheon: Human Brain Research \& Consulting Co.

Kim, Y. T., Hong, G. H., Kim, K. H., Jang, H. S., \& Lee, J. Y. (2009). Receptive \& expressive vocabulary test (REVT). Seoul: Seoul Community Rehabilitation Center.

Locke, J. L. (1980a). The inference of speech perception in the phonologically disordered child. Part I: a rationale, some criteria, the conventional tests. Journal of Speech and Hearing Disorders, 45, 431-444.

Locke, J. L. (1980b). The inference of speech perception in the phonologically disordered child. Part II: some clinically novel procedures, their use, some findings. Journal of Speech and Hearing Disorders, 45, 445-468.

Lof, G. L., \& Synan, S. T. (1997). Is there a speech discrimination/perception link to disordered articulation and phonology? A review of 80 years of literature. Contemporary Issues in Communications Sciences and Disorders, 24, 63-77.

Macmillan, N. A., \& Creelman, C. D. (2005). Detection theory: a user's guide (2nd ed.). Mahwah, NJ: Lawrence Erlbaum Associates.

Macmillan, N. A., \& Kaplan, H. L. (1985). Detection theory analysis of group 
data: estimating sensitivity from average hit and false-alarm rates. Psychological Bulletin, 98, 185-199.

Munson, B. (2001). Relationships between vocabulary size and spoken word recognition in children aged 3 to 7. Contemporary Issues in Communication Science and Disorders, 28, 20-29.

Nittrouer, S. (1992). Age-related differences in perceptual effects of formant transitions within syllables and across syllable boundaries. Journal of Phonetics, 20, 351-382.

Ohde, R. N., \& Sharf, D. J. (1988). Perceptual categorization and consistency of synthesized /rw/ continua by adults, normal children and /r/-misarticulating children. Journal of Speech, Language, and Hearing Research, 31, 556-568.

Prins, D. (1963). Relations among specific articulatory deviations and responses to a clinical measure of sound discrimination ability. Journal of Speech \& Hearing Disorders, 28, 382-388.

Rvachew, S., \& Grawburg, M. (2006). Correlates of phonological awareness in preschoolers with speech sound disorders. Journal of Speech, Language, and Hearing Research, 49, 74-87.
Rvachew, S., \& Jamieson, D. G. (1989). Perception of voiceless fricatives by children with a functional articulation disorder. Journal of Speech and Hearing Disorders, 54, 193-208.

Stackhouse, J., \& Wells, B. (1997). Children's speech and literacy difficulties: a psycholinguistic framework. San Diego, CA: Singular Publishing.

Stanislaw, H., \& Todorov, N. (1999). Calculation of signal detection theory measures. Behavior Research Methods, Instruments, \& Computers, 31, 137149.

Walley, A. C. (1988). Spoken word recognition by young children and adults. Cognitive Development, 3, 137-165.

Werker, J. F., Fennell, C. T., Corcoran, K. M., \& Stager, C. L. (2002). Infants' ability to learn phonetically similar words: effects of age and vocabulary size. Infancy, 3, 1-30.

Wilcox, K. A., \& Stephens, M. I. (1982). Childrens' identification of their own /s/ misarticulations. Journal of Communication Disorders, 15, 127-134.

Won, M. \& Ha, S. (2015). Final stop consonant perception in children with speech sound disorders. Communication Sciences \& Disorders, 20, 145156. 


\section{국문초록}

\section{말소리장애 아동의 말지각 연구: 어휘력과 자음정확도와의 관계 하승희}

한림대학교 언어청각학부

배경 및 목적: 만 4-6세 말소리장애 아동과 일반아동의 종성파열음에 대한 말지각 능력을 살펴보았다. 말지각 능력과 어휘력, 자음정 확도와의 관계를 분석함으로써 말소리 산출과 어휘 습득에 있어 말지각의 역할도 살펴보았다. 방법: 말소리장애 아동 33 명과 일반아동 35 명에게 두 쌍의 일음절 단어에서 종성파열음의 음향 정보를 모두 제공한 조건과 종성의 음향 구간 끝에서 $40 \mathrm{~ms}$ 와 $60 \mathrm{~ms}$ 씩을 잘라 낸 조건을 제시하였다. 아동의 반응을 d-prime 값으로 변환하여 분석하였으며 말소리장애 아동을 언어문제 동반 여부에 따라 두 집단 으로 분류하여 말지각 능력을 비교하였다. 회귀분석을 통해 말지각과 연령, 어휘크기, 자음정확도와의 관계를 살펴보았다. 결과: 음향 정보를 모두 제공한 조건과 $-40 \mathrm{~ms}$ 과 $-60 \mathrm{~ms}$ 의 게이팅 조건 모두에서 집단 간 d-prime 값이 유의미한 차이를 보였다. 전체와 $-40 \mathrm{~ms}$ 조 건에서는 단순말소리장애와 언어문제를 동반한 말소리장애 집단 간 차이가 유의미하지 않았으나 두 집단은 모두 일반아동과는 유의 미한 차이를 보였다. -60 ms 조건에서는 언어문제를 동반한 말소리장애 아동이 단순말소리장애 아동과 일반아동보다 말지각력이 유의 미하게 낮았다. REVT 수용어휘 원점수와 APAC 원점수가 유의미하게 말지각 능력을 예측하는 것으로 나타났다. 논의 및 결론: 본 연 구는 말소리장애 아동이 음향 정보가 완전한 조건에서도 말소리를 정확하게 감지하고 구별하는 데 어려움을 보이고, 말지각력이 어휘 와조음 능력과 관련 있음을 제시하고 있다.

핵심어: 말소리장애, 종성파열음, 말지각, 어휘력, 자음정확도

\section{참고문헌}

김두라(2006). 재미있는 언어치료(Vol 2. 조음음운장애 언어치료의 실제). 서울: 파라다이스 복지재단.

김민정, 배소영, 박창일(2007). 아동용발음평가(APAC). 인천: 휴브알앤씨.

김영태, 홍경훈, 김경희, 장혜성, 이주연(2009). 수용·표현어휘력검사(REVT). 서울: 서울장애인종합복지관.

김효진, 김미배, 진연선, 배소영(2013). 언어발달 촉진을 위한 우리말 카드. 서울: 학지사.

변경은, 하승희(2015). 4-6세 정상발달아동 및 성인의 종성파열음 지각력 비교. 말소리와음성과학, 7, 57-65.

원민주, 하승희 (2015). 말소리장애 아동과 일반아동의 종성파열음 지각력 연구. 언어청각장애연구, 20, 145-156.

조병순, 심현섭(2000). 기능적 조음장애 아동의 말소리 변별능력에 관한 연구. 언어청각장애연구, 5, 1-13. 